\title{
SOCIAL HOUSING IN WESTERN EUROPE IN THE NINETIES
}

Peter Boelhouwer and Harry van der Heijden

\section{Introduction}

Housing systems in Western Europe display a fair degree of similarity in their development. After the Second World War, governments became deeply involved in housing. Faced with housing shortages caused by the war, government policies were primarily directed toward large-scale housing construction programs. This was the heyday of the social rented sector in Europe.

In the mid-1970s, however, a shift occurred in the position of this sector within housing policy. At that time, housing shortages were declining. Meanwhile, insights in how to structure the welfare state were changing. Thus, at a growing pace, the social rented sector has been losing its dominant role to home ownership. Diverse causes for this development have been pointed out. Various authors have identified (a combination of) ideological and economic motives (see the contributions to this special issue).

Furthermore, the course these changes have taken in different countries is fairly similar. There was a general decline in public investment; there was a shift away from government regulation toward the market mechanism; the remaining government influence was decentralized; and the (declining) financial support shifted from generic to specific subsidies, targeted to the groups with the weakest socio-economic position.

Throughout Western Europe, this development was accompanied by (attempts at) privatization of the social rented sector. Lundqvist $(1992$, p. 3) considers privatization as a conscious public policy, regardless of the level of welfare provision. He defines it as "actions taken by actors legitimately representing the public sector to transfer the hitherto public responsibility for a certain activity away from the public and into the private sector." In practice, West European countries show differences in the division of competencies between the public and private sectors. At the same time, they show differences in the degree to which and the means whereby government policy is oriented toward a shift in competence from the public to the private sector. Nevertheless, we can distinguish several comparable efforts at privatization.

Neth. J. of Housing and the Built Environment, Vol. 9 (1994) No. 4. 
This trend has eroded, or already terminated, the opportunities to finance the construction and renovation of social rented dwellings with government loans. Increasingly, financing is arranged on the capital market. On the one hand, this shift reduces the size of the government budget. But at the same time, it often generates extra costs and risks for the social landlords, depending upon the means of subsidization. And this leads to higher housing costs. Furthermore, many countries are cutting back on subsidies for the production of social rented dwellings (affecting both the number of dwellings and the amount of funding received per unit).

The result is a general decline in new construction in the social rented sector and a rise in rents, because an ever larger share of the cost price must be covered by rental income. In addition, the cost price of newly built dwellings increased sharply, as productivity in building rose only slightly and income development stagnated (due to high unemployment rates).

Rent control in the social rented sector has already been (or soon will be) relaxed in various countries; the rents are increasingly conforming with the market. This trend is usually accompanied by an increase in individual subsidies, a politically sensitive issue.

During the 1980s, these developments led to a decline in accessibility to the social rented sector in many countries. Those affected most are the weakest groups in society. They often have to fall back on the poor-quality stock in the private rented sector. In France, England, and Belgium, this has increased the number of homeless people and households living in boarding houses. In fact, affordability problems occur not only among the lowest-income groups. Both England and Denmark (countries with a highly developed owner-occupied sector) have experienced severe crises on the homeowner market. In particular, households buying a home in the mid-1980s had trouble keeping up their mortgage payments and were faced with foreclosure.

Housing policy had to address two problems: it had to continue to provide housing for low-income households; and it had to keep the expenditure on individual subsidies under control, even though rents were rising. To accomplish this task, the housing authorities are trying to reserve whatever remains of the stock of inexpensive social rented dwellings for lower-income groups. But this effort is not without risk. It could pave the way for socio-economic segregation and could marginalize the social rented sector. In fact, that is already taking place -- notably in England and in parts of the low-quality stock in France. In countries where marginalization has largely been prevented thus far, another problem has arisen. There, many middle- and higherincome groups occupy dwellings in inexpensive parts of the stock of social rented dwellings. As a result, less well-to-do house hunters are often forced to take refuge in other segments of the housing market. In many cases, they move into the private rented sector. Otherwise, they settle for dwellings that do not fit their household or even fail to satisfy their demand for housing. Therefore, the issue of accessibility is under discussion in several countries -- the Netherlands, Sweden (for the cooperative sector), France, and Germany. These countries are considering measures to reduce the skewness in the distribution of the existing housing stock. In Germany, attempts to do the same have led to higher rent tax in the 1990s. That increase was implemented on a limited scale in the $1980 \mathrm{~s}$; by now, the government regards it as a proven and 
adequate housing instrument. In other countries -- for instance, France, the Netherlands, and Denmark -- the government is trying to influence the allocation policy of social landlords. France in particular has seen considerable conflict on this matter, where the HLM institutions and various authorities disagree.

Another problem concerns the conversion of social rented dwellings into private rented housing of owner-occupied dwellings. In several West European countries, governments have sought to divest themselves of their social housing stock. In some countries, this policy is recent; in others, it has been in force for a while.

The contributions that appear in this special issue of the journal highlight the developments sketched above. Most of these articles are based on papers presented at the 1993 ENHR conference, which was organized by the Metropolitan Research Institute for Sociology. That conference was called "Housing Policy in Central and Eastern Europe in the 1990s: Transformation in the East, Transference from the West."

Harloe's contribution places the social rented sector in an international perspective. He points out the differences in the structure of the social rented sector and in the policy for this sector in various countries. Furthermore, he notes some obvious similarities in the way the role of the social rented sector has developed in Western capitalistic societies. This development is described as a transition from a mass housing model to a residual housing model. The author goes on to identify which of these two is the normal housing model in Western capitalistic societies. It is not that of mass housing, which came into ascendancy after the Second World War, but rather the residual housing model. Accordingly, he sketches a pessimistic perspective for the future of the social rented sector.

Pryke and Whitehead review the implications that the 1988 Housing Act have for the way housing associations function in England. The aim of that Act is to achieve costeffective production of more social housing, supported by a reduced amount of publicsector funding and an increasing amount of private finance. Their contribution focuses on the effects of integrating private finance and social housing. The authors do not limit their discussion to the organizational consequences. They also broach the growing tension that is emerging between the housing associations' goal as providers of social housing and the cost implications of changing subsidy and finance regimes.

Teeland and Siksiö examine a specific measure of privatization in the Swedish housing system. This recent measure encourages municipalities to sell parts of the public housing stock to the sitting tenants. The policy entails the conversion of social rented dwellings into cooperatively owned dwellings. The authors compare the background of the Swedish policy with experiences in the rest of Europe. They analyze the diverse factors that determine the degree of success that is attained through this form of privatization. Their analysis goes beyond a discussion of the general economic situation and housing prices. In fact, the primary focus of the analysis is on the role played by location and dwelling type in the decision-making process in which the tenants decide to buy or not to buy their rented unit.

What are the repercussions of these developments for the role that the social rented sector can play in resolving the problems of housing provision in the 1990s? The 
contributions to this special issue are woven into our discussion of this question at the end of this introduction. But before we formulate an answer to our question, we review the position and the characteristics of the social rented sector in seven West European countries (see also Boelhouwer and Van der Heijden, 1992). We choose to focus on this topic because it cuts two ways. On the one side, the characteristics specific to each country largely determine the challenges that lie ahead for this sector in the nineties. On the other side, those characteristics also largely determine the possibilities to resolve the housing market issues that will emerge in the future.

\section{A further comparison of the social rented sector}

Any attempt to compare the social rented sector in different countries immediately runs into the problem of definitions. It is extremely difficult to find unanymity on how to describe the social rented sector. Several authors (Danermark and Elander, 1994; Harloe, 1994; Ruonavaara, 1993; Murie and Lindberg, 1991) have wrestled with this problem and offer practical advice to deal with it. For instance, Danermark and Elander $(1994$, p. 2) state that despite existing differences, there are still a number of fundamental characteristics that are fairly similar in each of the diverse countries. As summarized by Harloe (1994), social rented housing can be very broadly characterized as having three major characteristics. First, it is provided by landlords at a price that is not primarily determined by considerations of profit. Second, it is administratively allocated according to some conception of 'need'. Third, government control over social rented housing is extensive and has become more so over time.

Some objections may be raised to this definition, particularly with reference to the third characteristic. Nevertheless, we concur with the position taken by Danermark and Elander (1994) that Harloe's definition is acceptable for a comparative analysis of the social rented sector in Western Europe. Looking at social housing this way, the definitional issue seems to be turning into an empirical one, in the sense that its meaning must be contextualized with regard to the national setting (Danermark and Elander, 1994, p. 2).

In Table 1, we summarize the main characteristics of the social rented sector in the seven West European countries under review here. The first characteristic listed in the table is the proportion of the social sector in the total housing stock. The size of the social rented sector proves to vary considerably per country. With regard to size, the countries seem to form three groups: a) Belgium; b) Denmark, France, and Germany; and c) England, Sweden, and the Netherlands.

The smallest proportion is found in Belgium, where the social rented sector comprises only seven percent of the housing stock. The Belgian government has always regarded the promotion of home ownership as the central pillar of its housing policy. As a result, the function of the social rented sector is very modest. Lower-income groups are dependent upon the social rented sector. But to a large extent they also take recourse to the subsidized owner-occupied sector (notably for large families) and to the private rented sector. 


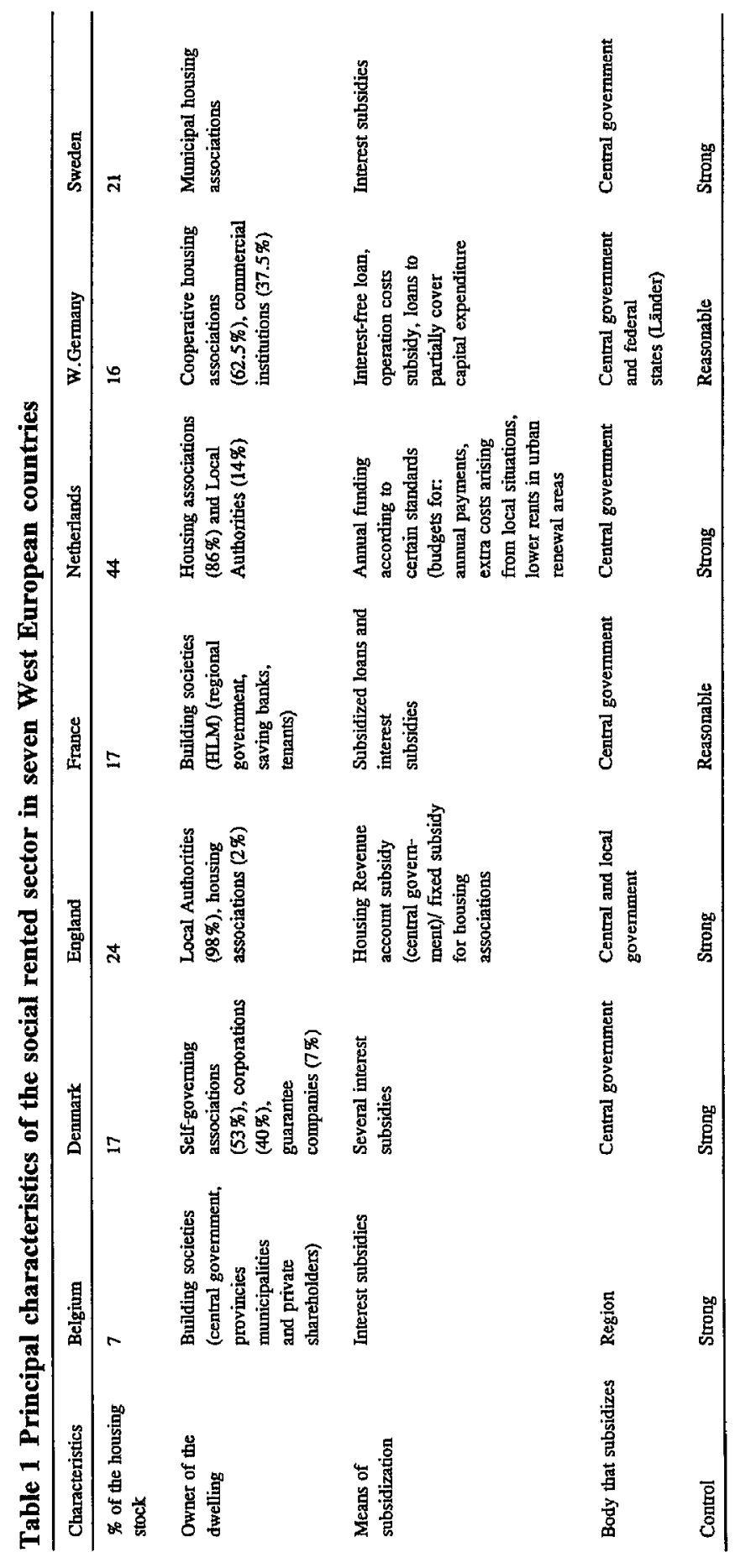




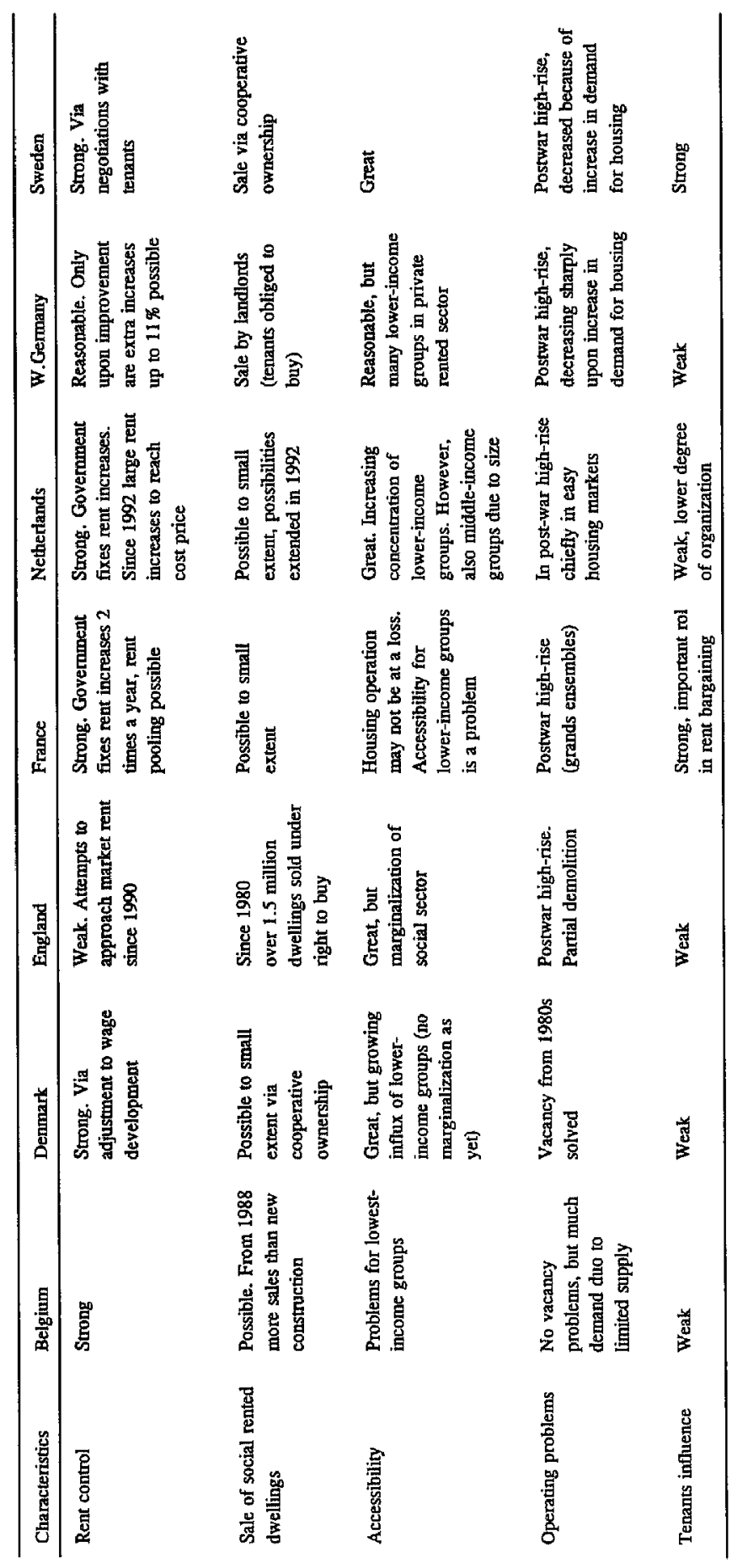


In the second group of countries, the social rented sector accounts for approximately 17 percent of the housing stock. These countries stimulated the development of the social rented sector but also assigned an important role to the private sector. In Denmark, the owner-occupied sector was clearly preferred. But in France and Germany, the private rented sector was also considered important.

The largest social rented sector was created in the third group of countries. The timing differed for each one, however. In England, the production of social rented housing was considerable in the first two decades after the Second World War. But in the $1970 \mathrm{~s}$, and particularly in the $1980 \mathrm{~s}$, there was a major reversal. The proportion of social rented dwellings dropped when over 1.8 million council dwellings were sold off. In Sweden, the production of social rented housing took place within a relatively short time span (1964-1975) under a program to build one million dwellings. This successful program had a great influence on the characteristics of the housing stock. To achieve the program's targets, many relatively small multi-family dwellings were constructed.

The social rented sector is very large in the Netherlands, representing 44 percent of the total housing stock. The main reason this sector is so large is that there was no policy to privatize housing until 1990 . In this respect, the Netherlands contrasts sharply with the other countries in this group. From 1945 until 1990, a large number of social rental units were built each year. Yet even though the volume of production was high, the housing shortage remained; the number of households kept growing in the meantime. The other countries in this group reached a state of equilibrium in the $1960 \mathrm{~s}$ or $1970 \mathrm{~s}$. Accordingly, as the reason for the extensive government involvement dissipated, housing production was left to the market.

The social rented sector in the countries under review here differs in more ways than size alone. The tenure structure is also quite different. First of all, England and Sweden have municipal housing companies, whereas the other countries have housing associations or societies. This diversity is manifest in the variety of ways in which the respective governments eventually introduced privatization measures. For instance, the English government was able to implement its proposal to sell off council housing (see Harloe's article in this issue). In other countries, such proposals often foundered on legal restrictions.

The countries also show marked differences in the way their social rented sectors are operated. For instance, the government has a strong representation on the boards of the building societies in Belgium and France as well as in the self-governing associations in Denmark. This is not the case in Germany or the Netherlands (where 86 percent of the stock of social rented dwellings falls outside the purview of government). The organizations that operate social rented housing in these countries act more like intermediaries between the government and market agents. Parties seeking to build in the social rented sector only have to comply with the government regulations for operators of social housing.

There is a major difference between countries with regard to the means of subsidization. In particular, the distinction between mortgage interest subsidies and annual outlays to defray operating expenses is significant. Belgium, Denmark, France, and Sweden provide mortgage interest subsidies. The main advantage of this 
arrangement is that it is fairly easy for the government to adjust the amount of subsidy when that is deemed necessary. There is much less leeway for adjustment in the case of operating subsidies. The difference between rental income and operating costs is covered by subsidy for the term of the loan. In the Netherlands, this is arranged separately for each loan (that is, for loans that were taken out before 1992). In England, this applies to the operation of the entire municipal housing company. In the event of long-term agreements, the amount of subsidy can only be reduced by raising the rents (generally an unpopular measure).

There is greater similarity among the countries with regard to the party that provides the subsidy. In six of the seven countries under review, the point of issue is the central government. In Belgium, the region is responsible for issuing the subsidy. The reason for Belgium's unique stance is the trend toward regionalization there, whereby the role of the central state has been greatly contracted. Germany's situation deviates slightly from the general picture. Besides the central government, Germany also has a federal structure in which the Länder shoulder a considerable part of the subsidy burden. And in England, until recently, the councils were able to make up any deficits by way of their housing corporation. Thus, the councils could pursue a policy of keeping rents down. However, recent changes in the law have made the separation between competencies more strict.

There are two traditions in setting rent levels. One is based on standardization; the other is based on the cost price. In the former, the government determines the rent that is considered appropriate for newly built dwellings. The difference between this normative rent and the actual cost price is then supposed to be subsidized by way of mortgage interest subsidies or operating subsidies. In that event, the operator has to meet strict quality requirements and adhere to maximum standards. After all, the system provides no incentive for the managers of social rented housing to keep costs down. On the other hand, when the rent is set on the basis of cost price, this incentive is present. Then, higher quality is directly translated into a higher level of rent. Recently, two changes have been introduced in the Netherlands and England: to provide subsidies in more standard amounts; and to balance the operating budget with rental income.

In all seven countries, security of tenure and rent control are strong in the social rented sector, whereas such regulation is weak in the private sector. With the exception of the Netherlands and Sweden, all of these countries apply liberal regimes to their private rented sector. Accordingly, the rents may vary widely between the two sectors. Belgium, England, and (only recently) the Netherlands can also apply a differentiated rent policy within the social stock (known as rent pooling). Belgium even has an individualized system, whereby the rent is determined the basis of the tenant's income. In Germany, high-income tenants who occupy units in the social rented sector can be assessed a rent tax. The proceeds of this assessment are used to subsidize new construction.

Most of these seven countries are trying to promote the sale of social rented dwellings. However, this has only been successful in England, Belgium, and Germany. In England, for example, over 1.8 million council houses have been sold since 1979. Home ownership is widely propagated in Belgium. Because the local housing authorities occupy a strong position in the building societies, the ownership of many rented 
dwellings has been transferred to the occupants. For this reason, and as a result of the low volume of new construction by the building societies, the stock of social rented dwellings has decreased even in absolute terms in recent years. In this respect, Belgium has come to resemble England.

In Germany, the sale of rented dwellings is considered an undesirable development by the government. As soon as the cheap state credits that have been used to obtain financing are redeemed in full, the operator is no longer obligated to keep a costeffective rental unit in the pool of social rented dwellings. In this context, speculators buy up whole blocks of social housing. Then they redeem the outstanding government credits, after which they proceed to sell the dwellings. In this way, speculators cash in on the indirect tax subsidies provided in the past, and they do so legally. Incidentally, the governments of the Länder are not always opposed to such practices. Actually, the premature redemption of government credits puts money back into the nearly empty subsidy fund. Thus, resources become available to construct new social housing for rent.

Especially in cities such as Munich, Hamburg, Cologne, and Düsseldorf, the sale of rented dwellings to tenants is a major problem. The decline in the proportion of social rented dwellings in the stock is intensified by several trends. One of these is the sale of rented dwellings. Another is the smaller proportion of social rented units in new construction. And yet another is the fact that the loans extended for many social rented dwellings that were built in the 1950 s and 1960 s have been largely redeemed. At that point, the landlords (including many private individuals) are free to rent out the units at the market rate. As a result, the social rented sector erodes further.

The reason for the limited success of the programs to sell off social rented housing in the other countries lies in the relatively strong position of the non-profit landlords. It is very difficult for the government to force a private organization to sell. In Sweden and Denmark, the conversion of rented apartments is only permitted if they are transferred into cooperative ownership. As Teeland and Siksiö point out in their contribution to this special issue, rental units in the private sector were converted to cooperative ownership at a fairly large scale in the 1980s. Their article reveals that the conversion of social rented dwellings did not catch on for various reasons, despite active government encouragement since late 1991.

\section{Conclusions}

In this introduction to the special issue, we have argued that the social rented sector has developed along similar lines throughout Western Europe. Privatization appeared (or reappeared) in many countries in the 1960 s or 1970 s, depending on when the housing shortage was abated. The share of social rented dwellings in the total housing production has declined. And home ownership is (once again) regarded as the most desirable housing sector.

However, a more detailed comparison of these countries reveals an entirely different picture. Great differences occur among these seven countries in the functioning and the position of their social rented sector. The specific position of this sector in each country 
is largely determined by the unique characteristics of that housing system as well as by the function of the social rented sector within the system. A process unique to each country shaped the structure of its housing market. Their institutions have evolved in the course of time. And the actions of their governments are strongly tinged by ideology and steeped in tradition. In sum, the structures, institutions, and government policies of the seven countries are highly divergent.

These differences partly determine the ways in which governments can proceed toward the privatization of the social stock in their country. At the same time, these differences partly determine the role that the social rented sector can play in resolving the problems of housing provision in the 1990s.

The numerous problems that have emerged in (parts of) the housing market in various countries since the end of the 1980 s may be classified under a few headings. Housing shortages have been (re)appearing, both in a quantitative and a qualitative sense. A gap has arisen between tenure sectors, and these sectors have become physically segregated. Accessibility to the housing market has decreased for groups with a weak socioeconomic position. And financial problems are increasing among lower-income households, but also for more affluent homeowners.

These problems are most acute in England, Germany, France, and Belgium. There, as early as the 1960 s and 1970 s, the government formulated policies to allow market forces to play a more prominent role in housing provision and to limit support for the social rented sector. At first, these countries were fairly successful in implementing their privatization measures. That success may be attributed to three developments. First of all, the quantitative housing shortages had been abated for the most part. Secondly, incomes had shown a favorable development. Thirdly, considerable (financial) support was made available by the government (especially in England, France, and Belgium) for the intended growth in home ownership. In contrast, the problems that emerged in the housing market at the end of the 1980s were caused in part by stagnation in economic development. Their appearance has revived the awareness of housing issues in those countries, both among the public at large and in political circles.

In the same period, funding for the social rented sector came under fire in Denmark, Sweden, and the Netherlands. These are countries where the political support for the social rented sector had been strong, until that point. At that time, the welfare state was under pressure. Accordingly, the policy emphasis shifted toward a reduction in generic subsidies and a divestment of the social rented sector. The divestment policy entailed either transfer to an independent operator or privatization. The retreat of government has had several repercussions. It has caused (further) decline in the volume of new construction in the social rented sector. And it has led to higher rents in a period when the number of low-income households was growing. The rent hikes for low-income groups is (partially) compensated by the provision of housing allowances. The availability of a sufficient number of dwellings that are accessible to low-income households is under pressure, however. In these countries, the availability of that housing sector is increasingly dependent upon the rate at which middle-income groups move out of the inexpensive rental units and into more expensive rentals or, especially, into owner-occupied dwellings. Under these constraints, the housing options for lowerincome groups become increasingly dependent upon economic conditions and the related 
developments on the market for owner-occupied housing. In countries where government policy is directed toward the conversion of social rented housing into owneroccupied units, the dependency upon (price) developments in the homeowner market is obvious. This point is elaborated in the contribution by Teeland and Siksiö.

In these countries, there is only limited evidence of marginalization of the social rented sector, and there are few signs of physical segregation (see Siksiö and Teeland's and Harloe's contributions elsewhere in this special issue). Of course, more factors are at play than the size of the social rented sector. The degree to which alternatives for the social rented sector are present, particularly for households with a low income, is also an important factor. In addition, the income distribution in a country is significant in preventing marginalization and segregation. For example, England's social rented sector, comprising 24 percent of the housing stock, is still quite large in comparison to Sweden's (with 21 percent) and Denmark's (with 17 percent). At the same time, evidence of marginalization of the social rented sector is much stronger in England than in the other two countries.

In the previous section of this introduction, we pointed out that (most of) the social rented sector in West European countries is owned by private non-profit organizations. As the government retreats from housing, these organizations (and with them, the social rented sector) gain a more independent position on the housing market. According to the contributions by Pryke and Whitehead and by Harloe, the sector should therefore act like a market party. And that means they would become more dependent upon economic developments and should accept the financial risks this entails. Under such conditions, the social goals of the sector are at odds with the demands made by financial independence. One aim is to guarantee financial independence for the long term. Another aim is to prevent or mitigate the marginalization and stigmatization of the sector. To achieve these aims, not only low-income households have to be housed; the housing system must be able to accommodate middle-income groups as well. It is necessary to have a differentiated housing supply and a differentiated population of renters in order to pursue a responsible rent policy. The same conditions apply to limiting the financial risks and to raising the image of the sector or keeping it up. Some countries have a better chance of attaining these goals. Sweden, Denmark, and the Netherlands have more opportunities to do so than countries where the social rented sector has been under pressure for a longer period and where marginalization and stigmatization have already made inroads into (parts of) the sector.

As a result of economic and demographic developments, the number of households with a low income has increased over the past few years in Western Europe. Meanwhile, the dismantling of the welfare state continues. For many low-income households, home ownership is unattainable. In many countries, the private rented sector offers limited options for low-income groups. These developments pose a serious challenge to the social rented sector. It can perform a crucial task as many countries cut back on government support. These countries increasingly gear their policy toward a social rented sector that can operate independently. The self-financing operation of social housing would be complemented primarily by selective housing allowances. It remains to be seen whether or not the social rented sector in these West European countries can actually perform this task adequately. That will depend greatly on the 
degree to which the social objectives of social rented housing can be combined with the demands made upon a housing sector that seeks to operate more or less independently.

\section{References}

Boelhouwer, P.J., and H.M.H. van der Heijden (1992), Housing Systems in Europe: Part I. A Comparative Study of Housing Policy, (Housing and Urban Policy Studies 1), Delft: Delft University Press.

Danermark, B. and I. Elander (1994), Social Rented Housing in Europe: Policy, Tenure and Design, (Housing and Urban Policy Studies 9), Delft: Delft University Press.

Harloe, M. (1994), The social construction of social housing, in: B. Danermark and I. Elander, Social Rented Housing in Europe: Policy, Tenure and Design, (Housing and Urban Policy Studies 9), Delft: Delft University Press, pp. 37-52.

Lundqvist, L.J. (1992), Dislodging the Welfare State? Housing and Privatization in Four European Nations, (Housing and Urban Policy Studies 3), Delft: Delft University Press.

Murie, A., and G. Lindberg (1991), Report of workshop held in Gothenburg, February 22-25 1991, working group on public and social rented housing, European Network for Housing Research.

Ruonavaara, H. (1993), "Types and forms of housing tenure: towards solving the comparison/translation problem", Scandinavian Housing and Planning Research (10), pp. 3-10. 